\title{
Symbole prawosławne $w$ filmach animowanych z ZSRR wyprodukowanych w latach 1948-1982
}

\author{
Katarzyna Lidia Babulewicz \\ Instytut Muzykologii Uniwersytetu Jagiellońskiego \\ Kraków, Polska \\ klbabulewicz@gmail.com
}

K. L. Babulewicz, Orthodox symbols in the animated films from the USSR, produced in 1948-1982, Elpis, $202018: 197-204$.

\begin{abstract}
The following article concerns Orthodox symbols that are present in selected animated films produced in the Soviet Union. Contrary to what one might expect from the films that were created during the reign of the socialist realist doctrine, religious references can often be found. They appear as details inherent in the world presented - primarily as orthodox churches and iconography. Sometimes the characters cross oneself, or there is a question that would not be expressed by the atheist or even the non-practicing person. Most importantly - in the vast majority of cases, these cancellations have no pejorative or sarcastic tone, which is surprising especially in the case of Stalinism era.

Streszczenie: Artykuł dotyczy symboli prawosławnych, które obecne są w wybranych filmach animowanych wyprodukowanych w Związku Radzieckim. Wbrew temu, czego można by się spodziewać po filmach powstałych w okresie panowania doktryny socrealistycznej, niejednokrotnie odnaleźć w nich można nawiązania do sfery religijnej. Pojawiają się one jako detale nieodłącznie wchodzące w skład świata przedstawionego - przede wszystkim jako cerkwie i ikonografia. Zdarza się, że postaci wykonują znak krzyża, bądź że pada kwestia, której nie wypowiadałby ateista, a nawet osoba niepraktykująca. Co najważniejsze - w zdecydowanej większości przypadków odwołania te nie posiadają wydźwięku pejoratywnego czy sarkastycznego, co dziwi szczególnie w przypadku produkcji powstałych w dobie stalinizmu.
\end{abstract}

Keywords: soviet animation, animation and orthodoxy, orthodox symbols in the animated films

Słowa kluczowe: animacja radziecka, animacja a prawosławie, symbole prawosławne w filmach animowanych

I

Hasło ,animacja radziecka” z jednej strony przynosi skojarzenia z ideologią krzewioną przez komunistów: z kolektywizmem, miłością do pracy i do człowieka pracy, poczuciem internacjonalistycznego obowiązku i dumą z ojczyzny. $Z$ drugiej strony przywołuje na myśl kadry z Wilka i Zajaca ${ }^{1}$ i innych seriali okresu odwilży, takich jak np. filmy o Krokodylu Gienie i Czeburaszcze ${ }^{2}$, Kot Leopold ${ }^{3}$, Troje z Prostokwaszyna ${ }^{4}$ - produkcje te nie tylko zawierają elementy satyryczne względem codzienności w schyłkowym okresie istnienia $\mathrm{ZSRR}^{5}$, lecz również mają walory kronikarskie, stanowią swego rodzaju dokumenty z epoki ${ }^{6}$. Naturalnie, w dorobku radzieckiej animacji odnaleźć można i liczne filmy propagandowe. Szcze-

\footnotetext{
Hy, nогодú!, 1969-2006, reż. W. Kotionoczkin, W. Tarasow, A. Kotionoczkin.

2 Odc. 1 - Крокодил Гена, 1969, reż. R. Kaczanow.

Кот Леопольд, 1975-1987, 1993, reż. A. Rieznikow.

Трое из Простоквашино, 1978, reż. W. Popow.

5 Midhat Ajanović pisze o ich ,humorystycznym pesymizmie”, za: Ülo Pikkov, On the Topics and Style of Soviet Animated Films, w: "Baltic Screen Media Review", t. 4, s. 29.

6 Pod tym względem szczególnie wart uwagi jest serial Wilk i Zając, przede wszystkim ze względu na ścieżkę dźwiękową, niemal w całości złożoną z cytatów muzycznych rozmaitej proweniencji (niejednokrotnie zachodniej). Te humorystyczne, misternie zbudowane muzyczne kolaże dają wyobrażenie o tym, jaki repertuar bliski był obywatelom ówczesnego ZSRR.
}

gólnie dużo powstało ich we wczesnym okresie ZSRR i w okresie stalinizmu. Niektóre z tych filmów, szczególnie wczesne mocno rażą propagandowym przekazem i trudno dostrzec w nich dodatkowe, niezwiązane z polityką przesłanie. Inne natomiast, przeciwnie - mówią o wartościach uniwersalnych, a o dacie ich powstania przypominają w głównej mierze detale warstwy wizualnej - jak czerwona gwiazda na baloniku niesionym przez dziewczynkę czy lalka Murzynka wręczona jubilatce? . Biorąc pod uwagę filmy powstałe do roku $1991 \mathrm{w}$ moskiewskim Sojuzmultfilmie, najważniejszej wytwórni ZSRR, dorobek radzieckiej animacji zwraca na siebie uwagę pod kilkoma względami. Imponującą jest nie tylko ogromna liczba wyprodukowanych filmów, ale też ich szerokie spektrum tematyczne - odnajdziemy zarówno scenariusze autorskie, jak i ekranizacje bajek ludowych, w tym również azjatyckich - i to nie tylko byłych Republik, a np. Japonii czy Chin, ponadto: mitologii greckiej, literatury rosyjskiej, a nawet - literatury zachodniej. Co więcej, filmy te prezentują zazwyczaj wysoki poziom artystyczny - zarówno pod względem warstwy wizualnej (stworzonej w różnorodnych technikach), jak i dźwiękowej (za oprawę muzyczną zawsze odpowiedzialni byli profesjonalni twórcy, muzyka powstawała specjalnie na potrzeby danego filmu,

\footnotetext{
Zob. Машенькин концеерт, 1948, reż. M. Paszczenko.
} 
co bardzo często wiązało się z pisaniem kompozycji na dużą orkiestrę symfoniczną $\left.{ }^{8}\right)$.

Dwudziesty wiek, jako epoka zapoczątkowana przez rewolucje (polityczne, naukowe, artystyczne), zaś zakończona postmodernizmem określany bywa mianem epoki upadku tradycji. Odchodzenie od religii, rozprzestrzenianie się ateizmu szczególnie wiązało się z ideami komunistycznymi. Tymczasem to filmy animowane zrealizowane akurat w ubiegłym stuleciu zasługują dziś na uwagę. Współczesna produkcja dedykowana najmłodszym widzom niejednokrotnie wzbudza poważne wątpliwości: gdy dominują w niej efekty specjalne, bohaterami są potwory, roboty, a przemoc jest na porządku dziennym - podobnie jak normą stał się często całkowity brak konstruktywnego przesłania, o kształtowaniu wrażliwości w oparciu o prawdy moralne nawet nie wspominając. Zdaniem psychologów najnowsze filmy dedykowane dzieciom mogą być groźne nie tylko dla ich rozwoju, ale nawet - dla zdrowia psychicznego. Niebezpieczne są: szybka zmiana kadrów, jaskrawość obrazu i częste błyski świetlne9. Niesione przez te filmy zagrożenia tłumaczyć można zapewne też w odmienny sposób. W aspekcie tematyki dzisiejszych dziecięcych bajek warto rozważyć słowa Michela Quenota:

Negowanie ducha pozostawia jedynie życie cielesne. Poplątanie przedmiotu i ciała ludzkiego redukuje człowieka do maszyny. Pewne zabawki i liczne obrazki kierowane do dzieci stwarzają niebezpieczeństwo pomieszania zwierzęcia, robota i człowieka. To pomieszanie rzeczy sztucznych i istot stworzonych, bytów żywych i mechanicznych, prowadzi do tego, że dzieci przestają postrzegać różnice, a przynajmniej je minimalizują ${ }^{10}$.

Zdecydowaną część filmów animowanych wyprodukowanych w ZSRR wyróżniają wartościowe scenariusze i obecność różnie pojmowanej sfery duchowej - jakkolwiek paradoksalnie to brzmi. Anna Kadykało podaje:

Reżyser Iwan Ufimcew stwierdził, że - w przeciwieństwie do rodzimych produkcji, przepełnionych serdecznością, szczerością, duchowym ciepłem - tym z zagranicy brakuje duszy: „Zamieniają ją wysokie technologie i jakaś jedna prościutka myśl w stylu jeśli będziesz odważny zwyciężysz, nie przeczę, niebezużyteczna dla dziecka. Ale jest ona tak bezduszna, wyjałowiona, że nie ma w niej ani trochę człowieczeństwa!’”11.

W Związku Radzieckim wytwórnie filmów animowanych finansowane były przez państwo. Przeciwnie niż miało miejsce w Stanach Zjednoczonych, animacja nie musiała na siebie zarabiać, co w oczywisty sposób stwarzało dobre warunki dla jej rozwoju i zapobiegało ukierunkowaniu na komercję. Z drugiej wszak strony, opieka

\footnotetext{
8 Niekiedy muzykę do filmów animowanych komponowali najbardziej uznani twórcy muzyki absolutnej, jak np. urodzony w Warszawie kompozytor pochodzenia żydowskiego, Mieczysław Wajnberg (zob. np. Винни-Пух, 1969, reż. F. Chitruk - ekranizacja Kubusia Puchatka A.A. Milne) czy Sofia Gubajdulina (zob. np. radziecka wersja Księgi Dżungli R. Kiplinga, czyli serial Maugli, 1967-1971, reż. R. Dawydow).

9 A. Kadykało, Dzieciństwo jako rosyjski temat kulturowy w XX wieku, Kraków 2014, s. 519.

10 M. Quenot, Ikona i kosmos, tłum. H. Paprocki, Białystok 2007, s. 39.

11 Kadykało, s. 516
}

państwa wiązała się z ograniczaniem swobody twórców za sprawą ingerencji cenzorskiej. Nie należy jednak nadużywać w kwestii oceny radzieckiej animacji argumentu istnienia cenzury ani wyolbrzymiać zasięgu jej działań. Innymi słowy - uogólniać. Jak podkreśla Ülo Pikkov: „Kiedy mowa o cenzurze w Związku Radzieckim, ważne jest, by uniknąć uproszczonej konfrontacji pomiędzy artystą i państwem - w społeczności twórców filmowych znajdowali się zarówno lojalni słudzy partii, jak i buntownicy przeciw reżimowi”'12. Scenariusze filmowe często daleko przekraczały ramy materializmu dialektycznego. Jak podejrzewać można już na podstawie nakreślonego wcześniej zakresu tematyki, nieraz pochylano się nad wątkami irracjonalnymi, niewytłumaczalnymi. W całej historii animacji radzieckiej pojawiały się różnorodne nawiązania do sfery ducha. W pierwszych filmach były to oczywiście konfrontacje z nową ideologią, deprecjonujące wszystko to, czego nie sposób objaśnić rozumem ${ }^{13}$. Później pojawiły się m.in. lubiane przez dzieci opowieści o zjawach ${ }^{14}$, opowieści nawiązujące do mitologii Słowian ${ }^{15}$, przede wszystkim jednak - czynione w sposób nienarzucający się nawiązania do chrześcijaństwa obrządku wschodniego. Odwołania te przybierają różną postać - pojawiają się $\mathrm{w}$ sferze wizualnej, jako mniej lub bardziej wymowne szczegóły, stanowiące nieodłączny komponent świata przedstawionego ${ }^{16}$, rzadziej w sferze audytywnej czy na gruncie fabularnym. Dość zaskakujący jest fakt, z jak dużą dokładnością były nieraz odwzorowywane prawosławne symbole ${ }^{17}$, biorąc pod uwagę produkcje dla dzieci, które zakładają zwykle sporą dozę umowności.

W jednej z najnowszych publikacji poświęconych animacji ZSRR - On the Topics and Style of Soviet Animated Films - Ülo Pikkov konstatuje:

Kiedy filmy animowane analizowane są jako dokumenty socjologiczne, to, co zostało z nich wykluczone staje się na równi ważne $\mathrm{z}$ tym, co jest $\mathrm{w}$ nich zawarte. $Z$ tego punktu widzenia ważne jest, by odnotować, iż radziecka animacja niemal nigdy nie podejmowała tematów religijnych - w przeciwieństwie do radzieckiego kina fabularnego, jak w przypadku dzieł Andrieja Tarkowskiego, a szczególnie jego Andrieja Rublowa (Андрей Рублёв, Rosja, 1966). Nawet gdy w niektórych filmach animowanych są

12 Ü. Pikkov, op. cit., s. 18. Wszystkie thumaczenia z języka angielskiego - K.B.

13 Zob.np. Chtopiec samojedzki (Самоедский мальчик, 1928, reż. N. iO. Chodatajew, W. i Z. Brumberg) - film opowiada historię chłopca, który ze śnieżnej Syberii na pokładzie statku czerwonoarmistów przybywa do Leningradu, gdzie podejmuje naukę. Obśmiane zostają wierzenia ludów Syberii - bohater demaskuje oszustwa szamana.

${ }_{14}$ Zob. np. Кентервильское привидение, reż. W. i Z. Brumberg, 1970, na podst. utworu O. Wilde'a.

15 Zob. Детство Ратибора,. 1973, reż. R. Dawydow.

16 Odnosi się wrażenie, że współcześnie w Rosji powstaje sporo animacji całkowicie poświęconych tematyce religijnej, zob. np. Святой преnoдобный Серафим Саровский Чудотвореи, 2009, reż. W. Ponomarew, A. Iwach).

17 Nie mniej zaskakujący jest fakt, iż odzwierciedlenie w multikach znalazły z jednej strony detale sztuki cerkiewnej, z drugiej - zabronione przez Cerkiew praktyki: w filmie z r. 1988 pojawia się postać szeptuchy (zob. Седой медведь, 1988, reż. L. Kajukow). 
przedstawiani duchowni, funkcjonują oni jako przestarzałe symbole reakcyjnej przeszłości, wraz z carami i carycami. Można by dowieść, że religijne tematy i symbole - tradycyjnie znajdujące się w centrum, niezwykle widoczne w słowiańskich społeczeństwach - stanowiły całkowite tabu w radzieckich filmach animowanych ${ }^{18}$.

W dalszej części artykułu postaramy się zweryfikować ocenę fińskiego badacza.

\section{II}

Rosyjska Cerkiew przez większą część dwudziestego stulecia nękana była mniej lub bardziej nasilonymi atakami ze strony bolszewików, którym to przyświecał cel zbudowania nowego porządku społecznego - bez Boga, a zatem i bez sztuki chrześcijańskiej. Jak powszechnie wiadomo, bezczeszczono miejsca kultu religijnego. Świątynie przemieniano w obory, garaże, magazyny, kina i więzienia $^{19}$. Ikony, księgi i naczynia liturgiczne były sprzedawane. Najbardziej radykalne działania podejmowane były przed wybuchem drugiej wojny światowej - na lata 19321937 przewidziana była realizacja tzw. bezbożnej pięciolatki - planu, który położyć miał ostateczny kres religii w Związku Radzieckim. Co znamienne, plan ten przewidywał m.in. stworzenie stu pięćdziesięciu antyreligijnych filmów, które miały być wyświetlane w szkołach ${ }^{20}$. Choć w późniejszym czasie prześladowanie chrześcijan nie było aż tak bezprecedensowe, jak w latach trzydziestych, to jednak ciągle obecne - tym bardziej ciekawa jest więc obecność symboli chrześcijańskich w animowanych produkcjach dedykowanych odbiorcy dziecięcemu - o którego to należyty rozwój Kraj Rad przejawiał szczególną troskę.

Mówiąc o symbolice religijnej w dwudziestowiecznych filmach, warto na moment udzielić głosu filmoznawcom. Zwłaszcza, że w dwudziestym pierwszym wieku, prawdopodobnie w związku z dużą popularnością badań interdyscyplinarnych, odnotować można zainteresowanie badaczy kwestią rozmaicie pojmowanych związków religii i kinematografii. Różnie definiowana bywa religijność w filmie, widać zwykle dążenie w kierunku: a) zawężania tej kategorii do filmów biblijnych, hagiograficznych i opowieści z życia duchownych, b) poszerzania granic pojęcia, za filmy religijne przyjmując wszelkie obrazy traktujące o poszukiwaniu sensu istnienia ${ }^{21}$. W kontekście naszych rozważań może nieco bardziej przydatna wydaje się teza sformułowana przez Henri Agela. Badacz wymienia trzy sposoby wyrażanie idei sacrum w kinie, są to: przedstawianie rzeczywistości jako misterium, wykorzystywanie ludowej tradycji i obyczajowości, od-

\footnotetext{
18 Ü. Pikkov, op. cit., s. 31.

19 I. Jazykowa, Oto czynie wszystko nowe. Ikona $w$ XX wieku, thum. H. Paprocki, Warszawa 2011, s. 61.

20 A. Grajewski, Najdtuższa religijna wojna XX wieku. $Z$ dziejów ateizmu w ZSRR, [w:] Chrześcijaństwo w Zwiąku Radzieckim w dobie pierestrojki i glasnosti : materiaty z sesji Eklezjologiczno-Misjologicznej, Pieniężno 28-30 IX 1989 , red. W. Grzeszczak, E. Śliwka, s. 86.

21 M. Kempna, Religijnośc jako paratekst. Na obrzeżach teorii filmu religijnego, [w:] Pogranicza audiowizualności, red. A. Gwóźdź, Kraków 2010, s. 243
}

najdywanie $\mathrm{w}$ wydarzeniach codziennych wymiarów transcendentnych ${ }^{22}$. Największy udział w analizowanych przez nas filmach będzie miał, jak się można spodziewać, „sposób” drugi, związany ze wschodniosłowiańskimi tradycjami.

Bajke o żotnierzu ${ }^{23} \mathrm{z}$ roku 1948 rozpoczyna widok maszerującego, wąsatego czerwonoarmisty. Mężczyzna ze śpiewem na ustach wchodzi do wioski. Przez moment widać złote kopuły cerkwi, a nad nimi krzyż (ze względu na nie najlepszą jakość filmu trudno ustalić, czy jest to krzyż łaciński, czy prawosławny). Sugeruje to, iż mieszkańcy miejsca, w które przybył są praktykującymi chrześcijanami. Wojak siada pod brzozą, a przed zjedzeniem kromki chleba zdejmuje czapkę i dwukrotnie się żegna. Nie jest to pusty gest - za moment pojawia się starzecżebrak. Żołnierzowi nieobce jest miłosierdzie: oddaje mu swój nader skromny posiłek, a sam zadawala się okruszkami. Później pomaga kolejnym bohaterom - w tym królowi, z którego zamku wypędza siły nieczyste.

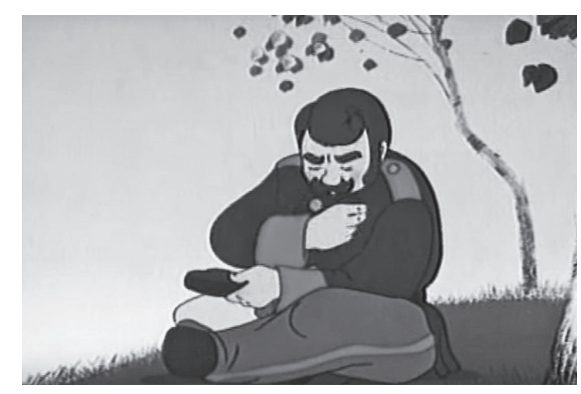

Ilustracja 1. Сказка о солдате,

1948, reż. W. i Z. Brumberg - żołnierz żegna się przed zjedzeniem chleba

Podobną liczbę mało wyeksponowanych odwołań do prawosławia zawiera zrealizowana dwa lata później ekranizacja Baśni o rybaku i złotej rybce $e^{24}$. Już krój pisma, który użyty został w czołówce nawiązuje do alfabetu starocerkiewno-słowiańskiego. Tytułowy rybak, jako reprezentant ludu jest głęboko wierzący - gdy uwalnia Złotą Rybkę, kieruje do niej słowa: „Bóg z tobą, Złota Rybko”. Kiedy na rozkaz żony trzykrotnie wraca nad morze, by porozmawiać ponownie z cudownym stworzonkiem, wita je z szacunkiem, wykonując - tak, jak w cerkwi - pojasny pokłon.

Znacznie wyraźniej przedstawione zostały prawosławne symbole $\mathrm{w}$ produkcji powstałej w roku 1951, a zatem zaledwie o rok później. Noc przed Bożym Narodzeniem ${ }^{25}$ na podstawie opowiadania N. Gogola Noc wigilijna rozpoczyna się widokiem wsi i ośnieżonych kopuł cerkwi. Słychać słowa narratora: Зимняя, ясная ночз

\footnotetext{
22 Za: M. Kempna, op. cit., s. 243.

23 Сказка о солдате, 1948, reż. W. i Z. Brumberg, na podst. rosyjskich bajek ludowych.

${ }^{24}$ Сказка о рыбаке и рыбке, 1950, reż. M. Ciechanowski, na podst. utworu A. Puszkina.

25 Ночь перед Рождеством, 1951, reż. W. i Z. Brumberg. Wykorzystano muzykę Nikołaja Rimskiego-Korsakowa, widać więc podwójny ukłon w kierunku rodzimej sztuki.
} 
наступила. Последний день перед Рожджеством прошел. Глянули звезды, месяи величал, поднялся на небо посветить добрым людям и всему миру, чтобы всем было весоло коледовать и славить Христа („Zapadła zimna, jasna noc. Minął ostatni dzień przed Bożym Narodzeniem. Gwiazdy spoglądały, ogromny Księżyc wspiął się po niebie, by poświecić dobrym ludziom i całemu światu, tak by wszystkim było wesoło kolędować i chwalić Chrystusa”). Następnie miejsce ma retrospekcja: poznajemy niesamowitą historię, w której, jak to u Gogola bywa, pojawia się ingerencja sił nieczystych. Za moment, co jest sytuacją raczej wyjątkową, widzimy też wnętrze świątyni, a konkretnie - fresk na sklepieniu. Jego pojawienie się zostało przez twórców filmu mocno wyeksponowane - nie dość, że malowidło jest dość długo widoczne (a w dodatku prezentowane najpierw w całości, następnie w przybliżeniu i raz jeszcze w planie ogólnym), zostaje omówione przez narratora. Dowiadujemy się, że to dzieło życia pewnego malarza. W pretwore cerkwi stworzył on scenę zbiorową z Sądu Ostatecznego: Święty Piotr ze swymi pomocnikami wygania diabła z piekieł. (Jak się dowiadujemy od lektora, dzieło to rozwścieczyło czorta, który to w ramach zemsty między innymi skradł niegdyś Księżyc). Jak może być przedstawiona apokaliptyczna przepowiednia w filmie animowanym? Otóż sama kompozycja przestrzenna fresku na pierwszy rzut oka przypomina malowidła obecne w świątyniach. Święty Piotr trzyma klucze od bram Raju, widać anioła, w tle Adama i Ewę kuszonych przez węża, jednak już po chwili dostrzega się żartobliwy szczegół: niektórzy ze świętych pomagających w walce $\mathrm{z}$ diabłem mają kozackie fryzury i charakterystyczne, zwężane w dole nogawki spodnie. Strażnik rajskich bram nosi kozackie buty, natomiast święty, który znajduje się najbliżej bestii, choć w nakryciu głowy i z siwą brodą, również jest Słowianinem - atakuje wroga nie mieczem, nawet nie bronią, lecz - brzozowymi pieńkami. Niżej od niego - w przestrzeni, a zatem i w hierarchii znajdują się też prawdziwi kozaccy wojownicy - umięśnieni, bez koszul, jak również - bez aureoli. Fresk jest najbardziej uchwytnym symbolem religijnym $\mathrm{w}$ całym filmie, pojawiaja się jednak i mniej wyeksponowane odwołania. W scenie w wiejskim domu widać wiszącą w rogu ikonę - została ona wzorowo ozdobiona ręcznikiem, jednak jedynie po układzie dwóch aureoli rozpoznać możemy, iż to ikona Bogurodzicy z Jezusem - tylko cudowne światła wyłaniają się z mroku, cała powierzchnia świętego obrazu pozostaje zaczerniona, co wydaje się niezwykle sugestywne. Ponieważ rozwój akcji związany jest z pojawieniem się sił nieczystych, ikona i fresk zyskują w tym filmie niejako nowy status - nie są już detalem, który sprawia, że krajobraz wygląda bardziej autentycznie. Przywrócone zostaje im właściwe znaczenie i wymiar metafizyczny. Warto też odnotować, że, jak przystało na film rozgrywający się w okresie bożonarodzeniowym, nie zabrakło akcentu związanego z tym świętem: pojawiają się kolędnicy, o których przynależności do obrządku wschodniego decydują niesione kolorowe gwiazdy.

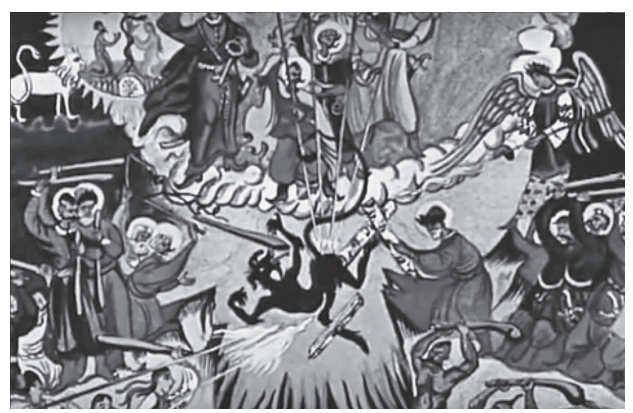

Ilustracja 2. Ночь перед Рождеством, 1951, reż. W. i Z. Brumberg - fresk w cerkwi

Szkarłatny Kwiat $^{26}$ z roku 1952, historia ojca, który wyrusza w zamorską podróż i obiecuje przywieźć swym córkom wymarzone prezenty, to kolejny przykład filmu, który rozpoczyna się widokiem złotych kopuł cerkwi. Tym razem mamy do czynienia z nową sytuacją - zmienia się miejsce akcji: nie jest nim już wieś, lecz miasto. W dodatku bogaty, nadmorski port (nad bramą grodu znajduje się nieczytelna, pozłacana ikona). Przeważa architektura drewniana, jest ona bajecznie ozdobiona, postaci noszą typowo słowiańskie stroje. Murowany, pobielony budulec wyróżnia tylko mury obronne - co zrozumiałe, a także, co bardzo wymowne - cerkwie. Jak widać świątynie muszą być wykonane z najlepszych materiałów budowlanych, odznaczają się w dodatku na tle brązowo-kolorowych domków, straganów itd., są poza tym monumentalne. W tym dobrze prosperującym ośrodku trudno wyznaczyć centrum - cerkwi jest dużo, a ich obecność jest wyraźnie eksponowana: widzimy w przybliżeniu kopułę i krzyż (trafiają na chwilę na pierwszy plan), dzwon. Co bardzo charakterystyczne, kopuły obecne są w różnych ujęciach - scenach z życia miasta, ich widok nie znika. Mieszkańcy spacerując, robiąc zakupy na targu, łupiąc orzechy w swym domu cały czas mają w zasięgu wzroku cerkwie, co sugeruje, że podobnie jest z obecnością Boga w ich codziennym życiu. Jak tłumaczy Michel Quenot:

Architektura zachowuje związek miejsca z przestrzenią, a świątynia symbolizuje kosmos. (...) W mieście pozbawionym centrum, a tym samym identyfikacji, ludzie czują się sierotami, istotami wykorzenionymi. Dzika przestrzeń jest zdezorientowana, natomiast uporządkowana wokół centrum staje się mikrokosmosem. Przestrzeń święta wprowadza wyłom w poziomie, ponieważ tworzy relacje ziemi i nieba, światłości i ciemności, materii i ducha. Pozwala to lepiej zrozumieć znaczącą rolę budowli w ikonografii ${ }^{27}$.

Wymowna jest w tym przypadku również klamra kompozycyjna filmu - kończy się on, podobnie jak zaczyna, widokiem portu, nad którym błyszczą złote kopuły. Tym razem widnieje nad nimi tęcza - symbol happy endu. Może warto też skojarzyć, że to symbol przymierza ze Starego Testamentu.

\footnotetext{
26 Аленький ицеточек, 1952, reż. L. Atamanow, na motywach bajki S. Aksakowa.

27 Michel Quenot, op. cit., s. 97.
} 

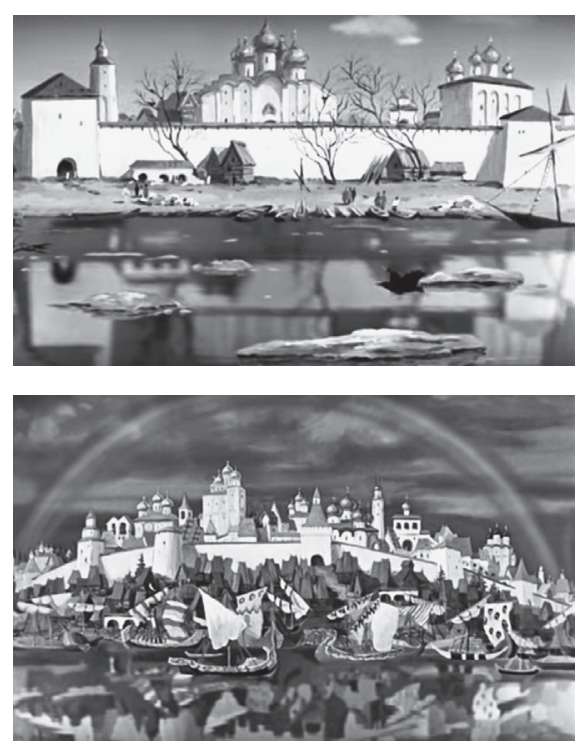

Ilustracje 3-4. Аленький цветочек,

1952, reż. L. Atamanow

Bajka o złotym koguciku ${ }^{28}$ na podst. utworu A. Puszkina, powstała już pod koniec kolejnej dekady, bo w roku 1967 przynosi zmianę pod względem estetyki: styl ilustracji staje się nowoczesny, humorystyczny, z jednej strony nawiązuje do rodzimego zdobnictwa, $\mathrm{z}$ drugiej - do malarstwa abstrakcjonistów, z trzeciej - do ówczesnej animacji

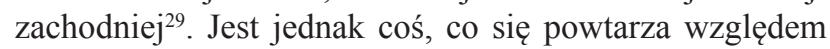
poprzednich przykładów filmowych - ponownie rozpoczyna widok kopuł cerkwi. Wyraźnie zarysowane zostały prawosławne krzyże, jest ich kilka. Tym razem mowa jest o wojnie. Królestwo, nad którym władzę sprawuje sędziwy władca zostaje zaatakowane przez oddziały wroga. Scenom ataku towarzyszą humorystyczne nawiązania do fresku - przedstawiają anioły z mieczami. Odwołania do sztuki malowania na mokrym tynku widać też niejednokrotnie w pałacu króla. Religijne skojarzenie przynosi malowidło z jeźdźcami konnymi, którzy mierzą w dół dzidami - podobnie jak w ikonografii św. Jerzy do smoka. Pojawia się też szczegół bardziej bezpośrednio odnoszący do sztuki cerkiewnej: nad bramą miasta wisi ikona. Przedstawia zapewne patrona osady - jest on ubrany w czarne szaty, wznosi ręce ku niebu w błagalnym geście.
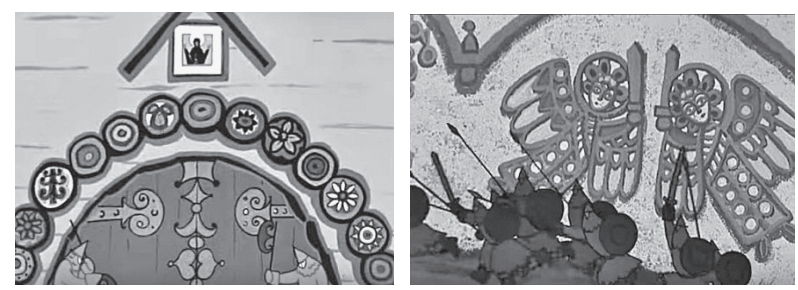

Ilustracje 5-6. Сказка о золотом петушке, 1967, reż. A. Snieżko-Błocka

\footnotetext{
28 Сказка о золотом петушке, 1967, reż. A. Snieżko-Błocka.

29 Radykalnej zmianie ulega też oprawa muzyczna - zamiast neoromantycznej symfoniki słyszymy tym razem brzmienia awangardowe, wykonywane m.in. przez fortepian preparowany.
}

O temacie wojny traktuje też kolejny przykład filmowy, Bitwa nad Kierżeńcem ${ }^{30} \mathrm{z}$ roku 1971. Trudno orzec, czy można ten film zakwalifikować do produkcji adresowanych do dzieci (a takie do tej pory były przedmiotem analizy), przez reżyserów raczej nie był on dedykowany najmłodszym widzom. Mimo wszystko nie sposób go tu pominąc - jest to prawdopodobnie najbardziej reprezentatywny przykład, a przynajmniej - najsilniej czerpiący z ikonografii. Tu mamy przypadek niemalże organicznego z nią związku. Film nawiązuje do staroruskiej legendy o niewidzialnym grodzie Kiteż. W XIII wieku za sprawą cudu powstrzymany został atak tatarski: dzięki modlitwom ruskiej ludności spod ziemi wystrzeliła woda i zatopiła oddziały gotowych do uderzenia Mongołów. W ten sposób powstać miało jezioro Swietłojar. W filmie zaprezentowany zostaje tylko wycinek opowieści - walka oddziałów rosyjskich $\mathrm{z}$ tatarskimi. W tym przypadku kluczowym dla nas zagadnieniem jest jednak nie sama opowieść, a inspiracja wizualna, za którą posłużyły twórcom ruskie freski i ikony z XIV-XVI wieku (informacja na ten temat pojawia się na początku filmu). Animacja stworzona została do muzyki z opery Nikołaja Rimskiego -Korsakowa pt. Legenda o niewidzialnym grodzie Kiteziu $i$ dziewicy Fewronii. Cały świat przedstawiony w filmie to rodzaj wycinanki - wszystko utrzymane jest w klimacie dawnych arcydzieł sztuki sakralnej. Postaci pochodzą z ikonografii - w rolach wojowników widzimy świętych, pojawia się wizerunek Świętej Rodziny, a nawet - thum Matek Boskich. Twórcom filmu nie można by było zarzucić, iż traktowane są one bez czci. Od początku do końca atmosfera jest bardzo podniosła.

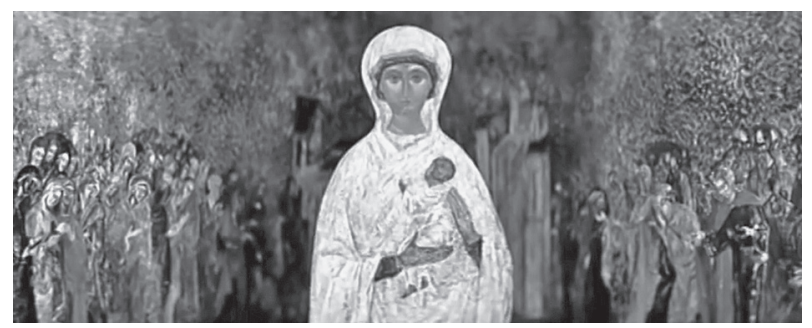

Ilustracja 7. Сеча при Керженце, 1971, reż. J. Norsztejn i I. Iwanow-Wano

Z biegunowo różnym podejściem do symboli religijnych mamy do czynienia w kolejnym przykładzie filmowym - w Bajce o popie i jego robotniku Bałdzie z roku $1973^{31}$ na podstawie satyrycznego utworu A. Puszkina ${ }^{32}$. Również i tu widok złotej kopuły i krzyża prawosławnego pojawia się zaraz po napisach, jednak w niepokojącej,

30 Сеча при Керженцее, 1971, reż. J. Norsztejn i I. Iwanow-Wano. Ülo Pikkov, pisząc o braku symboli religijnych w radzieckiej animacji wymienia ten film jako wyjątek.

31 Сказка о попе и о работнике его Балде, 1973, reż. I. Kowalewska.

32 Julian Tuwim przełożył ten utwór na język polski - w jego thumaczeniu tytuł brzmi Bajka o popie i o parobku jego Jołopie. Warto wspomnieć, że utwór ten, zapewne ze względu na zawartą w nim krytykę duchowieństwa, cieszył się w ZSRR popularnością wśród twórców filmów animowanych i był ekranizowany kilkakrotnie, a do wersji z roku 1933 (wytwórnia Lenfilm) muzykę skomponował Dymitr Szostakowicz. 
„cyrkowej” kolorystyce, a przede wszystkim w niepokojącym kontekście urbanistycznym. Jak możemy zauważyć w późniejszych scenach (bo zaraz po tej pierwszej pojawia się karuzela (!)), przed samą świątynią znajdują się: scena, targ, wesołe miasteczko, a nawet budki z napisami piwo, kwas, czaj... Tu więc nie cerkiew obecna jest w życiu codziennym ludu, lecz to świeckie uciechy obecne są w cerkwi. Co najsilniej przemawia oczywiście nie przez scenerię, a przez zachowanie tytułowego „popa”. Duchowny jest tęgi, łakomy, nie dzieli się jedzeniem z potrzebującymi. Zamiast zapłaty za zjedzoną wędlinę wykonuje nad wściekłym handlarzem znak błogosławieństwa (!). Nie dość, że wolno mu beztrosko tańczyć, bez szacunku odnosi się do krzyża, który nosi na piersi (akurat w tym przypadku, w przeciwieństwie do cerkiewnych kopuł wykorzystany został krzyż łaciński). Sam kapłan zresztą też nie budzi szacunku bohaterów, a zwłaszcza tytułowego Bałdy, wędrownego muzykanta, który w ramach szczęśliwego zakończenia opowieści daje mu pstryczka w nos, co powoduje, że duchowny ulatuje gdzieś wysoko w powietrze - w kierunku nieba, można więc $\mathrm{i}$ to odebrać jako sarkazm.

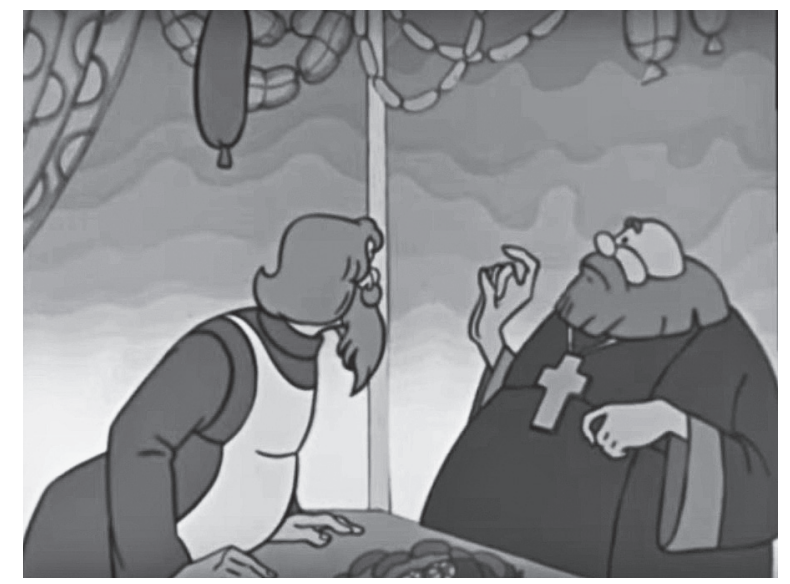

Ilustracje 8. Сказка о попе и о работнике его Балде, 1973, reż. I. Kowalewska

Kolejny film znów przenosi nas w czasy średniowiecznego księstwa, tym razem do Kijowa. Wasilisa Mikuliszna $(1975)^{33}$ opowiada historię tytułowej bohaterki, która, jako kochająca żona spieszy na pomoc swemu mężowi - kniaź Czernichowski został wzięty w niewolę i trafił do dawnej stolicy Rusi, dokąd ukochana wyrusza w męskim przebraniu. Tutaj symbole religijne ponownie stają się elementami scenerii - za oknami biesiadnej sali pałacu widać kopuły cerkwi (z wyraźnymi krzyżami), zaś podczas uczty zza pleców biesiadników wyglądają freski, a z nich - postaci w aureolach. Warto odnotować, że w tym przypadku ikonami inspirowany zdaje się być również styl rysunku, jeśli chodzi o twarze głównych bohaterów - mają charakterystyczny układ oczu i nosa i podniesione wysoko tuki brwiowe.

\footnotetext{
3 Василиса Микулищна, 1975, reż. R. Dawydow.
}

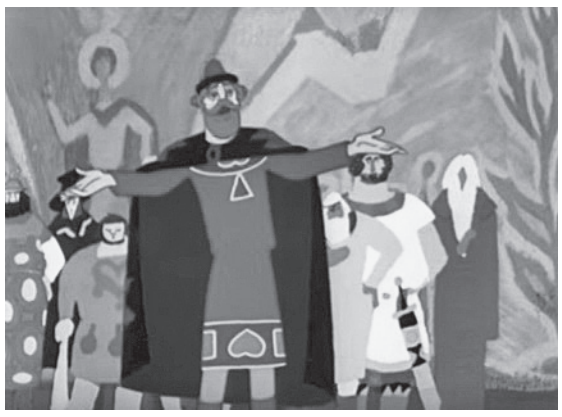

Ilustracje 9. Василиса Микулишна, 1975, reż. R. Dawydow

Podobną funkcję pełnią ikony w filmie z roku 1977 pt. Srebrne kopyta ${ }^{34}$, choć tu nie w kontekście dworskim, lecz wiejskim: film oparty został na motywach bajki P. Bażowa, pisarza czerpiącego z folkloru Uralu. Opowiada o losach dziewczynki, która zaadoptowana została przez samotnie mieszkającego staruszka. W pierwszej scenie widać górską wieś, w kolejnej - wnętrze drewnianego domostwa i jego mieszkańców. Jest to początkowe miejsce zamieszkania sieroty: widzimy rodzinę wielodzietną, której doskwiera bieda. W izbie nie ma nic, widać stół i ławy - w kącie, na półeczce ustawiono mimo wszystko aż trzy ikony (nie są czytelne). Ikona (tym razem można wywnioskować, że Bogurodzicy z Chrystusem) jest też i w nowym mieszkaniu dziewczynki, czyli u tajemniczego starca.

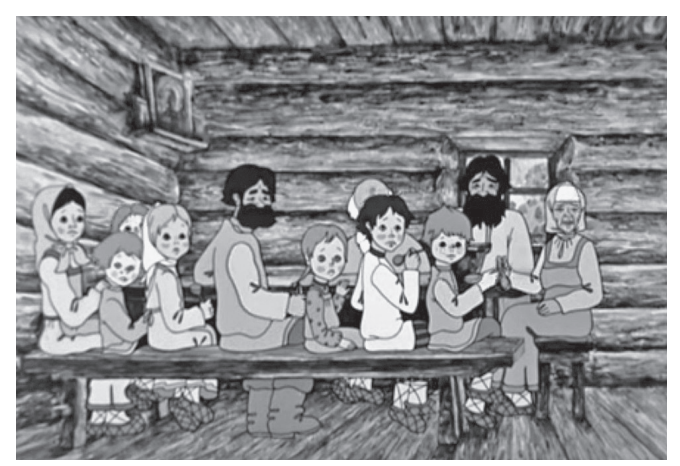

Ilustracje 10. Серебряное копытие,

1977, reż. G. Sokołowski.

Łabędzie Niepriadwy ${ }^{35}$, film z roku 1980 ponownie przenosi nas w czasy wojen średniowiecznych - zrealizowany on został ku upamiętnieniu rocznicy zwycięstwa Rusów nad wojskami Złotej Ordy w bitwie na Kulikowym Polu (1380). Ponownie w krajobrazie pierwszej sceny zarysowana jest cerkiew, świątynie (z zewnątrz) odwzorowane będą bardzo szczegółowo - jedna monumentalna, druga drewniana, tu jednak najbardziej wyróżniający na tle wcześniejszych przykładów będzie duży udział symboli religijnych w kontekście wojennym. Wielokrotnie pojawiają się wojskowe sztandary - z wizerunkiem Chrystusa, a także ze świętymi. Przed rozpoczęciem bitwy książę Dymitr wyrusza w dodatku po błogosławieństwo do św. Ser-

34 Серебряное копьтще, 1977, reż. G. Sokołowski.

35 Лебеди Непрядвы, 1980, reż. R. Dawydow. 
giusza z Radoneża (w przypadku tej postaci zarysowany został strój duchownego, święty trzyma w dłoni złoty, prawosławny krzyż). Przez chwilę pojawiają się zatem i postaci mnichów - przerywają oni swe pszczelarskie prace, by oddać ukłon przybyłym wojownikom. Na terenie klasztoru widać też otwarte wejście do drewnianej cerkwi (a nad nim ikonę) - z wnętrza dobiega śpiew męskiego chóru.

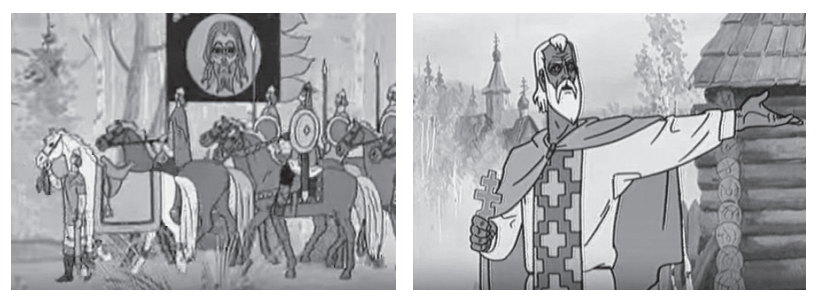

Ilustracje 11-12. Лебеди Непрядвы,, 1980, reż. R. Dawydow

$\mathrm{Na}$ podstawie ludowej bajki, tym razem ukraińskiej oparty został ostatni przykład, któremu poświęcona będzie uwaga - Byt sobie pies ${ }^{36}$ (1982). W filmie tym zauważa się sporą dbałość o oddawanie realiów ukraińskiej wsi - widać charakterystyczne zdobienia na strojach bohaterów, detale architektoniczne, a w dodatku jedyna muzyka, jaka się pojawia, to nagrania terenowe pieśni. Film opowiada historię czworonoga pilnującego wiejskiego podwórka, w niczym nie przypomina ona jednak perypetii polskiego Reksia ze Studia Filmów Rysunkowych w Bielsku-Białej. Tu zapłatą za wieloletnią, pełną poświęcenia służbę gospodarzom jest wypędzenie do lasu. W lesie, przed targnięciem się na swe życie ratuje psa jego wróg - wilk. Niespodziewanie to bohater nie tylko pozytywny, lecz nawet - uduchowiony, wypowiada on bowiem słowa: „Boże, pomóż!”. Okazuje się bardziej miłosierny niż ludzie, którzy jednak mają w swej izbie cztery ozdobione białymi ręcznikami ikony. W rogu pomieszczenia wisi prawdopodobnie ikona św. Mikołaja, zaś obok niej - trzy nieczytelne ikony, nad którymi jest jeden ręcznik.

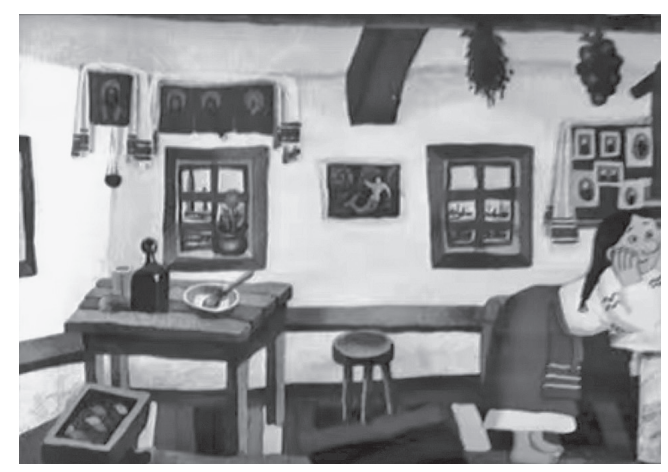

Ilustracje 13. Жил-был пес,

1982, reż. E. Nazarow.

$* * *$

Analiza kilku wspomnianych wyżej filmów pozwala wysnuć pewne wnioski na temat rodzajów wprowadzonych

36 Жил-был пес, 1982, reż. E. Nazarow. do ich warstwy wizualnej symboli sakralnych i ich znaczenia. W zdecydowanej większości omawianych filmów w krajobrazie widniejącym w pierwszym kadrze - czy to miejskim, czy wiejskim - jest cerkiew, zwykle o złotych kopułach. Widok wnętrza świątyni stanowi wyjątek. Bohaterowie filmów wykonują rytuały religijne w sposób przyporządkowujący ich do obrządku wschodniego: żegnają się od prawej strony do lewej, biją pokłony, wzywają Boga na pomoc, udzielają błogosławieństwa. Do rzadkości należy pojawienie się duchownych - w jednym przypadku kapłan zostaje sparodiowany, w innym jednak filmie pojawiają się nawet święci. Ikony, choć często nieczytelne, widoczne są we wnętrzach wiejskich domostw i nad bramami średniowiecznych miast; nie udało się odnaleźć ikon w bajkach rozgrywających się w dwudziestym wieku. Pojawienie się w filmie animowanym świętego wizerunku to pozornie szczegół - zapada on jednak w pamięć widza, sprawia, iż tym bardziej staje się dla niego czymś naturalnym. A chyba takim ma być, jak czytamy w podręczniku do nauki religii prawosławnej: „Z dawien dawna ikony miały znaczenie kształcące i wychowawcz ${ }^{37}$." Z drugiej strony - nadaje znaczenia transcendentnego. Oczywiście nie błahym przygodom bohaterów, przypomina raczej o istnieniu wymiaru ducha. ,(..) ikona zwiastuje przemienienie ziemi, nową ziemię i nowe niebo, zwiastowanie kulminujące w obecności Zmartwychwstałego, który wszystko pociąga i w którym wszystko się spełni. (...) Cały dialog teologiczny na temat przemienienia dotyka ikony, ponieważ podnosi ona zasłonę z najgłębszej rzeczywistości oraz łączy materię i ducha, czas i wieczność ${ }^{38}$ ".

Warto raz jeszcze podkreślić, że, wbrew temu, czego można by się było spodziewać, to nie chęcią wymierzenia ataku wobec Cerkwi podyktowane było umieszczenie w świecie przedstawionym omówionych filmów symboli religijnych. Odnosi się wrażenie, jak by było wręcz przeciwnie - a twórcom przyświecał cel, by choć nienarzucającym się szczegółem wpisać swą opowieść w narrację chrześcijańską, harmonizującą $\mathrm{z}$ wyobrażoną w filmach rzeczywistością historyczną.

Przy obecnym stanie badań można jedynie domniemywać, dlaczego w tak wielu filmach radzieckich, i to zarówno w popularnych produkcjach okresu odwilży, których twórcy nie byli już tak silnie skrępowani przez cenzurę, jak i w filmach z okresu stalinizmu zaznaczona została więź z chrześcijaństwem - wydaje się, że twórcy traktowali religię jako nieodłączną część rosyjskiej tradycji, gloryfikowanej w prawie każdym filmie. Trudniej natomiast odpowiedzieć na pytanie, dlaczego akcenty religijne znikły $z$ animacji powstałych w schyłkowym okresie istnienia ZSRR, w których z jednej strony dopuszczono elementy zachodnie (np. Wilk i Zając czy Bremeńscy muzykanci), z drugiej - pojawiły się odwołania do „ducha narodu”, objawiające się choćby specyficznym liryzmem (ścieżki dźwiękowe Krokodyla Gieny i Kota Leopolda nawiązują

37 Podręcznik do nauki religii prawosławnej, cenzor diecezjalny ks. mitrat dr Serafin Żelezniakiewicz, Białystok 1984, s. 15.

38 Michel Quenot, op. cit., s. 81. 
wyraźnie do poetyki romansu rosyjskiego, obaj bohaterzy są ostentacyjnie staromodni). Tymczasową i bynajmniej nie zadowalającą odpowiedzią może być obserwacja, iż symbole religijne na dobre zniknęły z europejskich bajek dziś - w czasach pełnej wolności słownej, religijnej i światopoglądowej.

\section{Bibliografia}

Animacja, [w:] J. Bauman, R. Jurieniew, Mała encyklopedia kina radzieckiego, Warszawa 1987.

Grajewski A., Najdluższa religijna wojna XX wieku. Z dziejów ateizmu w ZSRR, [w:] Chrześcijaństwo w Związu Radzieckim $w$ dobie pierestrojki i głasnosti: materialy z sesji Eklezjologiczno-Misjologicznej, Pieniężno 28-30 IX 1989 , red. W. Grzeszczak, E. Śliwka, s. _

Jazykowa I., Oto czynię wszystko nowe. Ikona w XX wieku, thum. H. Paprocki, Warszawa 2011.

Kadykało A., Dzieciństwo jako rosyjski temat kulturowy wXX wieku, Kraków 2014.
Капков С., Эничиклопедия отечественной мультипликаичи, Москва 2007.

Kempna M., Religijność jako paratekst. Na obrzeżach teorii filmu religijnego, [w:] Pogranicza audiowizualności, red. A. Gwóźdź, Kraków 2010, s.

Pikkov Ü., On the Topics and Style of Soviet Animated Films, [w:] "Baltic Screen Media Review" 2016, t. 4, s. 16-37.

Podręcznik do nauki religii prawosławnej, cenzor diecezjalny ks. mitrat dr Serafin Żelezniakiewicz, Białystok 1984.

Quenot M., Ikona i kosmos, tłum. H. Paprocki, Białystok 2007.

Rozmiar artykułu: 1,2 arkusza wydawniczego 


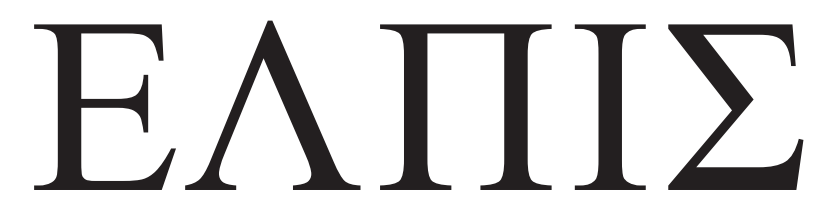

CZASOPISMO TEOLOGICZNE KATEDRY TEOLOGII PRAWOSŁAWNEJ UNIWERSYTETU W BIAŁYMSTOKU

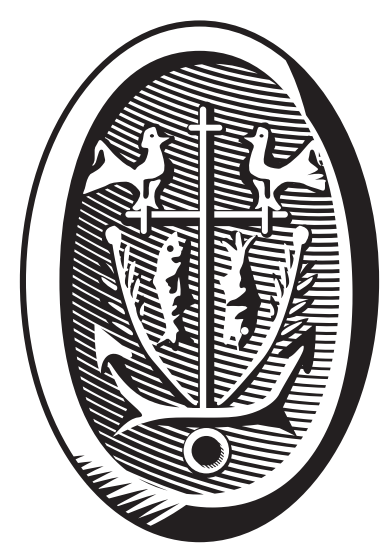

ADRES REDAKCJI

ul. Ludwika Zamenhofa 15, 15-435 Białystok, Polska tel. 85 745-77-80, e-mail: elpis@uwb.edu.pl www.elpis.uwb.edu.pl 